\title{
Memenangkan Loyalitas Pelanggan Melalui Corporate Social Responsibility Di Pasar Air Minum Kemasan
}

\author{
Arum Wahyuni Purbohastuti, Widya Nur Bhakti, Muhammad Johan Widikusyanto \\ Fakultas Ekonomi dan Bisnis, Sultan Ageng Tirtayasa \\ Email :arum_wp@untirta.ac.id \\ Fakultas Ekonomi dan Bisnis, Sultan Ageng Tirtayasa \\ Email : Widyong@gmail.com \\ Fakultas Ekonomi dan Bisnis, Sultan Ageng Tirtayasa \\ Email : mjohanw@gmail.com
}

\begin{abstract}
Abstrak
Persaingan yang ketat dipasar air minum kemasan memaksa setiap pemasar di Industri ini menggunakan strategi pemasaran yang efektif untuk bertahan dan memenangkan persaingan dengan menciptakan loyalitas pelanggan. Penelitian ini bertujuan untuk menguji model penelitian yang menggambarkan peran CSR dalam membangun loyalitas pelanggan di pasar air minum kemasan dengan melibatkan dua variabel lain sebagai mediator yaitu kepuasan pelanggan dan kepercayaan. Hasil penelitian ini diharapkan dapat meningkatkan kemampuan pemasar air minum kemasan untuk menghadapi persaingan di pasar yang mereka perjuangkan.

Pendekatan dalam penelitian ini adalah kuantitatif dan kausal. Pengumpulan data dilakukan dengan menyebarkan kuesioner kepada 200 konsumen air minum dalam kemasan di kota Serang dengan teknik Accidental sampling. Teknik analisis yang akan digunakan adalah Structural Equation Modeling (SEM) dengan bantuan perangkat lunak AMOS.
\end{abstract}

Temuan penelitian ini membuktikan bahwa CSR memengaruhi kepuasan dan kepercayaan pelanggan. Kepuasan terbukti memengaruhi kepercayaan dan loyalitas terhadap sikap pelanggan. Kepercayaan pelanggan terbukti berpengaruh pada Loyalitas Sikap. Kepuasan dan kepercayaan tampaknya tidak berpengaruh pada Loyalitas Perilaku.

Kepuasan dan kepercayaan adalah variabel yang memediasi pengaruh CSR pada loyalitas sikap. Dengan demikian, CSR dapat meningkatkan loyalitas pelanggan dengan meningkatkan atau meningkatkan kepuasan dan kepercayaan pelanggan mereka.

Kata kunci: CSR, Loyalitas, Kepuasan, Kepercayaan 


\section{PENDAHULUAN}

Persaingan bisnis saat ini semakin berkembang dengan banyaknya perusahaan bergerak di bidang bisnis yang sama dengan konsumen yang semakin teliti dalam mengambil keputusan. Salah satunya perusahaan air minum mineral yang ada di Indonesia semakin banyak yang memproduksi air minum mineral dalam kemasan. Merek air minum mineral di Indonesia antara lain Aqua, Ades, Ades Royal, nestle Pure Life, Aguaria, Sega, Aira, Club, Fuji, Cleo, dan Vit.

Dengan berkembangnya zaman serba praktis, maka banyak orang yang enggan untuk sekedar memasak air, oleh sebab itu hal ini menjadi salah satu situasi yang dimanfaatkan oleh produsen untuk memenuhi kebutuhan dengan menyediakan air mineral yang langsung bisa dikonsumsi tanpa harus dimasak lagi. Aqua salah satu produk yang tetap eksis melayani kebutuhan air minum mineral, walaupun banyak pesaing baru yang bermunculan.

Pada dasarnya penelitian ini untuk melihat dampak Corporate Social Responsibility (CSR) yang dilakukan oleh Aqua dalam menciptkan loyalitas pelanggannya. Aqua merupakan salah satu perusahaan yang gencar melakukan program CSR. Semakin banyaknya pesaing, maka Aqua menitikberatkan perhatiannya pada pelanggan, salah satunya dengan merancang program CSR sehingga konsumen mempunyai loyalitas terhadap produk Aqua. Loyalitas pelanggan telah diakui selama beberapa dekade untuk menciptakan bisnis yang sukses (Chaudhuri dan holbrook, 2001;Day, 1969; Dick dan Basu, 1994). Ada beberapa cara yang dipakai perusahaan untuk meningkatkan loyalitas nasabah diantaranya CSR dimana tanggung jawab sosial perusahaan telah digunakan dalam studi degan menggabungkan model loyalitas pelanggan. Namun, sebagian besar penelitian tentang CSR dilakukan di negara barat, sedangkan di Asia masih relatif sedikit (Chapple dan Moon, 2005). Selain itu, Masih sedikitnya perusahaan di Indonesia yang benar-benar memanfaatkan CSR sebagai strategi membangun loyalitas pelanggan, menjadi dasar pentingnya hasil penelitian ini bagi mereka.

\section{Tujuan Penelitian}

Berdasarkan gambaran di atas, maka tujuan penelitian ini dapat dikelompokkan menjadi :

\section{Tujuan Umum}

Penelitian ini secara umum bertujuan untuk mengembangkan penelitian Mandhachitara dan Poolthong (2011)dengan menambahkan variabel kepuasan pelanggan dan mengganti variabel kualitas pelayanan dengan kepercayaan pelanggan sehingga variabel yang saling mempengaruhi antara CSR, loyalitas sikap dan loyalitas perilaku pelangan. Sampel yang diambil dalam penelitian yang dilakukan oleh Mandhachitara dan poolthong (2011) yaitu pada nasabah Bank, sedangkan pada penelitian ini sampelnya pada 
pelanggan Aqua sehingga untuk kualitas pelayanan dari karyawan tidak ada. Oleh karena itu variabel Kualitas Pelayanan diganti dengan Kepercayaan Pelanggan.

\section{Tujuan Khusus}

Berdasarkan tujuan umum di atas, maka dapat diperoleh tujuan khusus dari penelitian ini sebagai berikut :

a. Menguji pengaruh CSR terhadap kepercayaan pelanggan

b. Menguji pengaruh CSR terhadap kepuasan pelanggan

c. Menguji pengaruh kepuasan pelanggan terhadap kepercayaan pelanggan

d. Menguji pengaruh kepuasan pelanggan terhadap loyalitas pelanggan, baik loyalitas sikap maupun perilaku.

e. Menguji pengaruh kepercayaan pelanggan terhadap loyalitas pelanggan, baik loyalitas sikap maupun perilaku.

\section{Urgensi Penelitian}

Sebagian besar penelitian tentang CSR dilakukan di negara barat, sedangkan di Asia masih relatif sedikit (Chapple dan Moon, 2005; Salmones et. al, 2005). Dengan demikian, penelitian ini akan menambah bukti empiris serta kontribusi ilmiah dan praktis mengenai CSR dan Loyalitas di Asia, khusunya Indonesia. Selain itu, Masih sedikitnya perusahaan di Indonesia yang benar-benar memanfaatkan CSR sebagai strategi membangun loyalitas pelanggan, menjadi dasar pentingnya hasil penelitian ini bagi mereka yang akan membantu mereka melihat strategi CSR adalah penting dan perlu mendapat perhatian dalam membangun loyalitas guna bertahan dalam persaingan yang semakin keras.

\section{STUDI PUSTAKA}

\section{Loyalitas Pelanggan}

Konsep loyalitas pelanggan didasarkan pada sikap pelanggan dan niat perilaku terhadap barang atau jasa yang ditawarkan dan melakukan pembelian ulang (Day, 1969;Dick dan Basu, 1994). Dick dan Basu (1994), memberikan penjelasan tentang hubungan antara kekuatan sikap (attitude strength) dan repeat patronage. Kritikan yang dikemukakan oleh Day (1969), mengungkapkan bahwa tidak cukup jika mengukur loyalitas hanya berdasarkan perilaku saja, karena berarti tidak akan ada perbedaan antara true loyalty dan spurious loyalty. Spurious loyalty berasal dari pembeli yang tidak memilikiketerlibatan dengan atribut merek, sehingga mereka akan mudah berpindah ke merek lain yang menawarkan keuntungan yang lebih baik. Untuk memecahkan masalah potensial tersebut, Day (1969) mengusulkan konsep loyalitas dua dimensional, dengan tetap menggunakan dimensi perilaku (behavioral) dan menambahkan dimensi sikap (attitudinal).

Griffin (2003), memberikan pengertian loyalitas mengacu pada suatu perilaku yang ditunjukkan dengan pembelian rutin yang disarkan pada unit pengambilan keputusan. Dari 
pendapat di atas, maka dalam penelitian ini untuk mengukur loyalitas dapat dilihat dari segi sikap dan perilaku.

Ada beberapa indikator dalam mengukur loyalitas menurut Roberts, et, al, 2003 antara lain :

a. Kesediaan berbagi informasi (share information)

b. Menyampaikan hal positif penyedia jasa ke orang lain (say positive things)

c. Merekomendasikan penyedia jasa kepada orang lain (recommended friends)

d. Melakukan pembelian secara kontinyu (continue purchasing)

e. Membeli jasa layanan tambahan (purchase additional service)

f. Menguji jasa layanan baru (test new service)

Setiap orang mempunyai tipe loyalitas yang berbeda, dimana tipe loyalitas itu sangat mempengaruhi terhadap kemajuan perusahaan. Apabila pelanggan merasa bangga sebagai pengguna suatu produk dan merekomendasikan serta mempromosikan produk tersebut kepada pihak lain, maka efek positifnya sangat dirasakan oleh perusahaan. Berbagai tipe loyalitas, maka perusahaan harus bisa menterjemahkan keinginan pelanggan agar semua pelanggan memiliki tipe yang loyalist.

\section{Corporate Social Responsibility}

Menurut Chahal dan Sharma (2006), CSR didefinisikan sebagai kewajiban perusahaan untuk melindungi dan meningkatkan kesejahteraan sosial masyarakat dan sekaligus perusahaan, baik dalam masa sekarang mau pun masa mendatang melalui berbagai upaya bisnis maupun tindakan sosial, dan memberikan keyakinan bahwa hal tersebut akan menghasilkan keuntungan yang seimbang dan terus menerus (sustainable) dalam jangka panjang bagi semua stakeholders. Pada Tahun 2005, CSR didefinisikan sebagai komitmen untuk meningkatkan kesejahteraan masyarakat melalui kebijakan praktik bisinis yang dipilih dan kontribusi dari sumber daya perusahaan (Kotler dan Lee, 2005). Pengukuran program CSR pada air minum kemasan Aqua yaitu dengan adanya program yang dilakukan oleh Aqua seperti pembangunan sumber air minum di Papua.Banyak sekali manfaat yang didapat dari adanya program CSR, sehingga semakin banyak pula perusahaan yang mencanangkan program tersebut. Dengan adanya program CSR, perusahaan mempunyai nilai yang positif dimata pelanggan. Oleh karena itu, perusahaan berlomba-lomba untuk melakukan program CSR dengan mempublikasikan di media agar semua orang tau apa yang telah dilakukanoleh perusahaan.

\section{Kepercayaan Pelanggan}

Nooteboom (2003) berpendapatbahawa kepercayaan pelanggan berhubungan dengan ketergantungan dan resiko, antara pemberi kepercayaan dan yang diberi kepercayaan. Menurut Weichrich dan koontz (2003), memandang konsep kepercayaan sama dengan integritas, loyalitas, perhatian dan memegang teguh janji. Dari beberapa indikator kepercayaan, bahwa terciptanya kepercayaan itu bisa dilihat dari kredibilitas di mana perusahaan diyakini oleh pelanggannya sehingga apa yang dilakukan oleh perusahaan tidak akan membuat pelanggan merasa ragu dalam mengkonsumsi produk maupun memeakai 
jasa. Kepedulian perusahaan juga mampu menciptakan kepercayaan, di mana kepedulian itu sebagai wujud bantuan dan perhatian. Biasanya pelanggan juga akan memperhatikan kepedulian yang dilakukan oleh perusahaan terhadap pelanggan, sehingga pelanggan semakin percaya terhadap perusahaan yang melakukan tindakan kepedulian.

\section{Kepuasan Pelanggan}

Bowen dan Chen (2001) menyatakan kepuasan pelanggan berhubungan erat dengan loyalitas pelanggan, di mana pelanggan yang terpuaskan akan menjadi pelanggan yang loyal. Kemudian pelanggan yang loyal tersebut akan menjadi tenaga pemasaran yang dahsyat bagi perusahaan dengan memberikan rekomendasi dan informasi positif kepada calon pelanggan lain. Penerimaan produk dengan kualitas yang lebih tinggi akan mendapatkan tingkat kepuasan yang lebih tinggi daripada penerimaan produk dengan kualitas yang lebih rendah (Kennedy et, al, 2001). Keuntungan perusahaan dengan menggunakan dimensi kepuasan pelanggan telah ditampakkan pada beberapa penelitian, diantaranya untuk mengevaluasi sikap dan informasi dari para tamu dan mengidentifikasi kekuatan dan kelemahan (Barsky dan Labagh, 1992). Dari uraian di atas tentang indikator kepuasan, maka kepuasan itu dapat diukur dengan menggunakan indikator kepuasan global, keselarasan antara kepuasan yang diharapkan dengan apa yang dirasakan, dan persepsi nilai di mana ketiganya saling mendukung untuk mengukur kepuasan pelanggan.

\section{Pengembangan Model Penelitian}

\section{Pengaruh CSR terhadap Kepuasan Pelanggan}

Program CSR dapat memungkinkan perusahaan untuk memahami apa yang diinginkan oleh pelanggan, sehingga pelanggan tersebut bisa menjadi pelanggan yang setia karena mereka merasa puas (Luo dan Bhattacharya, 2006). Dengan kata lain, penelitian menunjukkan bahwa inisiatif CSR mendorong pelanggan untuk mengembangkan rasa afektif, hubungan emosional kepada perusahaan yang ternyata dalam kepuasan ditingkatkan (Bhattacharya dan Sen, 2003). Kemudian di dalam penelitian yang dilakukan oleh Onlaor dan Rotchanakitumnuai (2010) di mana CSR mempengaruhi kepuasan pelanggan dan loyalitas pelanggan dalam persepsi tentang keadilan harga, kualitas layanan, dan kekhawatiran privasi akan berdampak pada kepuasan pelanggan yang pada gilirannya menyebabkan loyalitas pelanggan. Dengan demikian, hipotesis untuk hubungan antar variabel ini adalah:

\section{H1: CSR berpengaruh positif terhadap Kepuasan Pelanggan}

\section{Pengaruh CSR terhadap Kepercayaan Pelanggan}

Menurut Kwok Tak Yuen (2007) yang meneliti hubungan antara CSR, kepercayaan, dan loyalitas, menghasilkan bahwa dengan melakukan program CSR maka akan berpengaruh terhadap kepercayaan pelanggan terhadap perusahaan yang bersangkutan. Penelitian yang dilakukan oleh Barnes (2011), bahwa perusahan yang melakukan program CSR akan berpengaruh lebih besar terhadap kepercayaan pelanggan akan merek perusahaan tersebut, daripada perusahaan yang tidak melakukan program CSR. Menurut Wang (2011), penelitian yang dilakukan bertujuan untuk meneliti efek CSR dengan 
menguji hubungan antara sikap terhadap praktik CSR, kepercayaan terhadap perusahaan, sikap terhadap perusahaan, dan nilai perilaku. Dengan demikian, hipotesis untuk hubungan antar variabel ini adalah:

\section{H2: CSR berpengaruh positif terhadap Kepercayaan Pelanggan}

\section{Pengaruh Kepuasan Pelanggan terhadap Kepercayaan Pelanggan}

Sesuai dengan penelitian yang dilakukan oleh Nawaz dan Usman (2011) bertujuan untuk mengetahui faktor-faktor yang mempengaruhi loyalitas merek di sektor telekomunikasi. Menurut Menurut Dwyer, et al. (1987) dalam Jasfar (2012:16), kepercayaan adalah sebagai bentuk keyakinan pelanggan terhadap sebuah janji perusahaan yang bersifat reliable dan juga merupakan alasan dasar untuk menjalin hubungan dengan perusahaan. Dengan demikian, hipotesis untuk hubungan antar variabel ini adalah:

\section{H 3: Kepuasan Pelanggan Berpengaruh Positif Terhadap Kepercayaan Pelanggan}

\section{Pengaruh Kepuasan Pelanggan terhadap Loyalitas Pelanggan}

Penelitian yang dilakukan Sheng dan Liu (2010), menemukan bahwa efisiensi dan pemenuhan memiliki efek positif pada kepuasan pelanggan dan kemudian berpengaruh pada loyalitas pelanggan. Dengan demikian, hipotesis untuk hubungan antar variabel ini adalah:

\section{H4:Kepuasan Pelanggan berpengaruh positif terhadap Loyalitas Sikap}

H5:Kepuasan Pelanggan berpengaruh positif terhadap Loyalitas Perilaku

\section{Pengaruh KepercayaanPelanggan terhadap Loyalitas Pelanggan}

Plank dan Pullins (1999) mendefinisikan kepercayaan sebagai suatu kepercayaan yang dihasilkan dari evaluasi menyeluruh atas tenaga penjual, produk dan perusahaan. Kepercayaan merupakan konstruk yang merefleksikan kredibelitas (Ganesan, 2005) dimana mampu mempengaruhi orientasi jangka pelanggan dengan mengurangi persepsi atas resiko yang berhubungan dengan tingkah opurtunistik bagi perusahaan. Penelitian yang dilakukan oleh Chaudhuri dan Holbrook, (2001) menemukan bahwa kepercayaan merupakan penggerak yang mempengaruhi loyalitas merek pada benak pelanggan.Dengan demikian, hipotesis untuk hubungan antar variabel ini adalah:

\section{H6: KepercayaanPelanggan berpengaruh positif terhadap Loyalitas Sikap H7:KepercayaanPelanggan berpengaruh positif terhadap Loyalitas Perilaku}

Berdasarkan kerangka teoretis yang telah dibangun, maka model dalam penelitian ini yang akan diuji ditampilkan pada gambar berikut ini. 


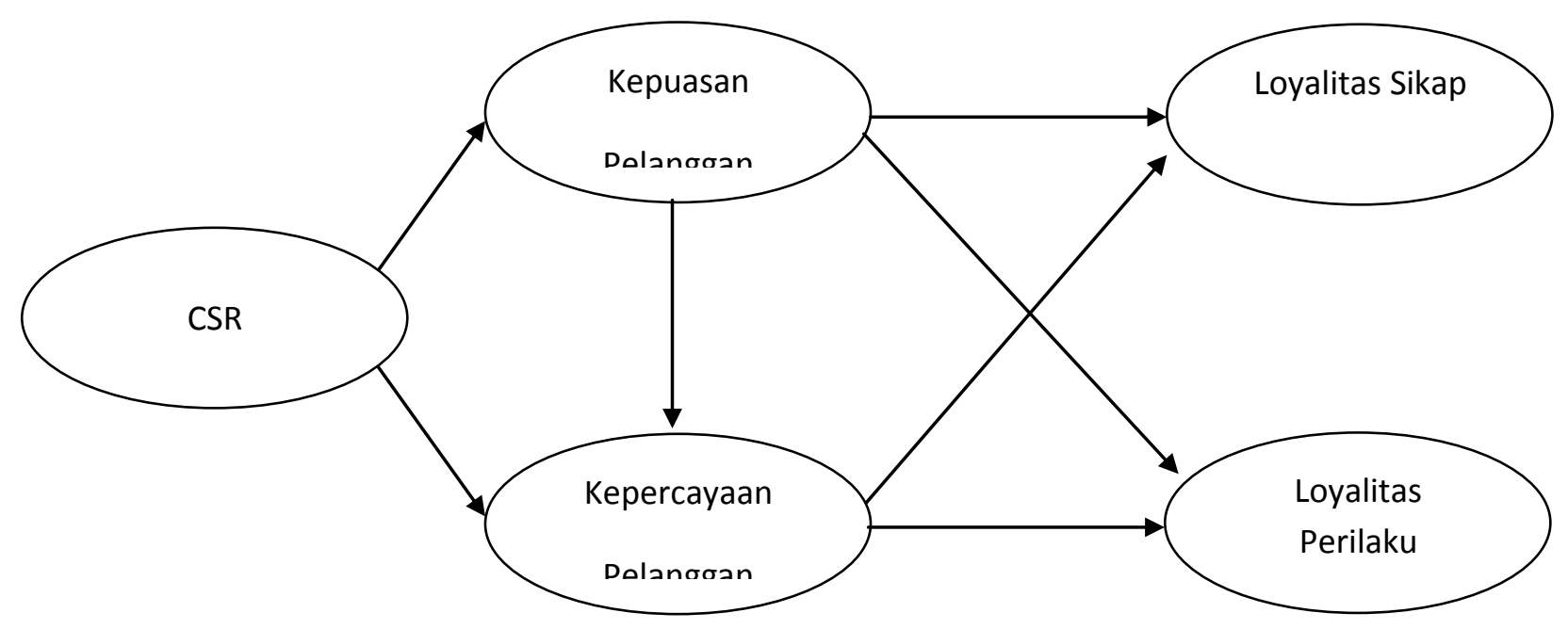

Gambar 2.1 Model Penelitian

\section{METODE PENELITIAN}

Alur proses penelitian ini ditampilkan pada bagan alir proses penelitian berikut ini.

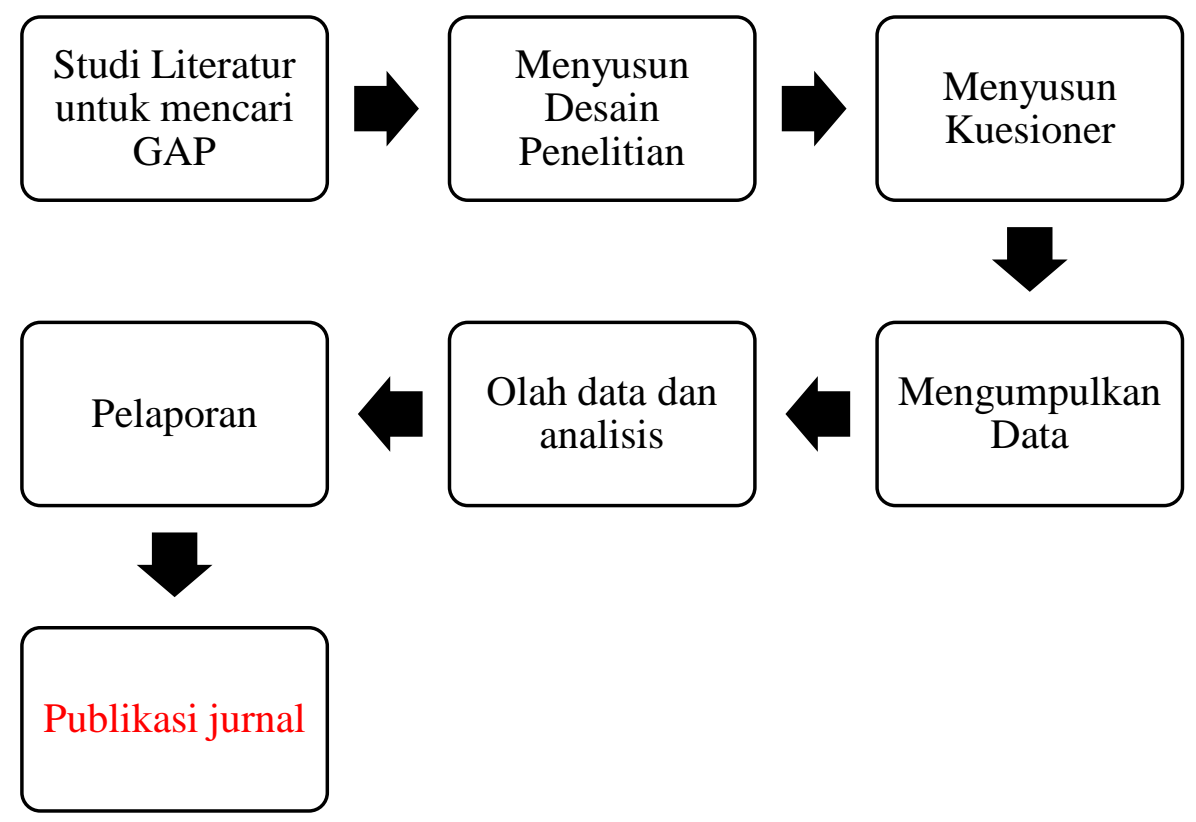

Gambar 3.1. Bagan Alur Proses Penelitian

Jenis penelitian yang dipilih dalam penelitian ini adalah kuantitatif dan bersifat kausalitas. Jenis penelitian ini dipilih karena model yang dihipotesiskan di dalam penelitian akan diuji secara kuantitatif atau statistik. Pedekatan ini sesuai dengan tujuan penelitian yang ingin mengonfirmasi model yang dihipotesiskan. Selain itu, penelitian ini bersifat kausal karena tujuan penelitian adalah mengonfirmasi hubungan kausal antara antesenden dengan konsekuensinya. Desain yang digunakan dalam penelitian ini adalah survey. 
CSR,Kepercayaan, Kepuasan, LoyalitasSikap dan LoyalitasPerilaku Pelanggan diukur menggunakan tujuh point. Skala yang digunakan mempunyai nilai skor dimana 1 sangat tidak setuju sampai dengan 7 sangat setuju.

Teknik sampling yang digunakan adalah Accidental sampling, dan sampelnya adalah pelanggan Aqua dari kemasan galon, botol, dan gelas yang sudah berlangganan maupun tidak.

Ukuran sampel ditentukan dengan cara mengalikan 19 butir pernyataan dengan rasio 10 sehingga ukuran sampelnya adalah 190. Untuk menghindari resiko sampel yang cacat dan tidak dapat diolah serta kemungkinan adanya outlier, maka sampel yang direncanakan ditambah 10 responden sehingga ukuran total sampel adalah sebanyak 200 responden.

Metode pengumpulan data yang digunakan adalah self-administered survey dengan cara menyebarkan kuesioner penelitian secara langsung pada responden.

Instrumen diuji construct Validity dan reliabiliy-nya. construct Validity akan diuji menggunakan analisis faktor confirmatory (CFA) dengan batas minimal nilai faktor loading setiap butir atau indikator adalah $\geq 0,5$, idealnya adalah 0,7 atau lebih tinggi (Hair et al., 2006: 777). Indikator atau butir pertanyaan dengan faktor loading dibawah 0,5 tidak akan diikutsertakan dalam analisis model struktural. Reliabilitas akan diuji menggunakan cronbach's alpha dengan koefisien cronbach's alphaminimal 0,60 (Hair et al., 2006: 778).

Analisis model penelitian menggunakan structural equation modeling (SEM) dengan bantuan program AMOS. Pengujian hipotesis dapat dilakukan setelah model memenuhi nilai GOF yang disyaratkan. Hipotesis diterima jika tingkat signifikansi hubungan antar variabel konstruk pada regression weights dari estimasi maximum likelihood memiliki nilai $p$ value $<0,05$ dan dengan melihat critical ratio yang harus memiliki nilai lebih besar dari nilai t table \pm 1,66 untuk uji satu sisi dengan tingkat alpha 0,05 .

\section{HASIL}

Pengujian Instrumen Penelitian

Validitas instrumen diuji menggunakan analisis faktor. Berikut ini tabel hasil uji validitas instrumen.

TABEL 1.1 Hasil Uji Convergent Validity

Rotated Component Matrix ${ }^{a}$
Component

1

2

3

4

5 


\begin{tabular}{|c|c|c|c|c|c|}
\hline csr1 & 664 & & & & \\
\hline csr2 & 507 & & & & \\
\hline csr3 &, 755 & & & & \\
\hline csr4 & ,796 & & & & \\
\hline csr5 & 794 & & & & \\
\hline csr6 &, 547 & & & & \\
\hline csr7 & ,586 & & & & \\
\hline ps1 & & & & & ,877 \\
\hline ps2 & & & & & ,801 \\
\hline ps3 & & & & & ,553 \\
\hline pc1 & & & & 773 & \\
\hline pc2 & & & & ,810 & \\
\hline pc3 & & & & 865 & \\
\hline Is1 & & 876 & & & \\
\hline Is2 & & 820 & & & \\
\hline Is3 & & 836 & & & \\
\hline Ip1 & & & ,867 & & \\
\hline Ip2 & & & ,883 & & \\
\hline Ip3 & & & ,923 & & \\
\hline
\end{tabular}

Indikator suatu konstruk laten harus converge atau share (berbagi) proporsi varian yang tinggi disebut convergent validity. Untuk mengukur validitas konstruk bisa dilihat dari nilai faktor loadingnya. Nilai loading yang tinggi pada suatu faktor menunjukan convergen pada satu titik. Syarat yang harus dipenuhi adalah loading factor harus significant dan nilainya harus lebih besar dari 0,5 dan idealnya adalah 0,7. Berdasarkan hasil tabel diatas, loading factor signifikan secara statistik dan nilainya sudah diatas 0,5. Beberapa butir dengan nilai loading factor di bawah 0,5 tidak digunakan untuk analisis lebih lanjut.

Reliabilitas instrument diuji dengan membandingkan nilai cronbach alpha masing masing variabel dengan cut-off value sebesar 0,7 . 
TABEL 1.2 Hasil Uji Reliabilitas

\begin{tabular}{|l|l|l|}
\hline Variabel & Cronbach Alpha & Kesimpulan \\
\hline CSR & 0,83 & Reliabel \\
\hline Kepuasan & 0,68 & Reliabel \\
\hline Kepercayaan & 0,836 & Reliabel \\
\hline Loyalitas Sikap & 0,874 & Reliabel \\
\hline Loyalitas Perilaku & 0,879 & Reliabel \\
\hline
\end{tabular}

Berdasarkan tabel diatas, terlihat bahwa kelima konstruk laten yang digunakan dalam penelitian ini memiliki koefisien cronbach alpha lebih besar dari 0,70. Dengan demikian dapat disimpulkan bahwa konstruk-konstruk laten yang digunakan dalam penelitian ini reliabel.

Pengujian model atau hipotesis diawali dengan pengujian Goodness of Fit Model (GOF). Terpenuhinya GOF menjadi syarat untuk analisis lebih lanjut.

TABEL 1.3 Goodness Of Fit Model

\begin{tabular}{|l|l|l|}
\hline Kriteria Indeks Ukuran & Nilai Acuan & Hasil \\
\hline Chi-Square $\left(\mathbf{X}^{2}\right)$ & Sekecil mungkin & 313,121 \\
\hline p-value & $\geq 0,05$ & 0,000 \\
\hline CMIN/DF & $\leq 5$ & 2,159 \\
\hline GFI & $>0,90$ & 0,858 \\
\hline AGFI & $>0,90$ & 0,813 \\
\hline CFI & $>0,90$ & 0,902 \\
\hline RMSEA & $\leq 0,08$ & 0,076 \\
\hline
\end{tabular}

Berdasarkan tabel diatas, model penelitian sudah dianggap Fit karena beberapa kriteria indeks ukuran terpenuhi, seperti CMIN/DF, CFI dan RMSEA.

Setelah model penelitian dianggap fit, maka selanjutnya adalah pengujian hipotesis. Pengujian hipotesis memperhatikan koefisien t-hitung dan nilai P. Berikut ini tabel pengujian hipotesis. 
TABEL 1.4 Pengujian Hipotesis

\begin{tabular}{|c|c|c|c|c|c|c|}
\hline Hipotesis & Hubungan Vaı & iabel & & C.R. & $\mathbf{P}$ & Hasil Uji \\
\hline 1 & CSR & $\Rightarrow$ & Kepuasan & 4,879 & $* * *$ & Terbukti \\
\hline 2 & CSR & $\Rightarrow$ & Kepercayaan & 4,737 & $* * *$ & Terbukti \\
\hline 3 & Kepuasan & $\Rightarrow$ & Kepercayaan & 2,540 & 0,011 & Terbukti \\
\hline 4 & Kepuasan & $\Rightarrow$ & Loyalitas Sikap & 2,972 & 0,003 & Terbukti \\
\hline 5 & Kepuasan & $\Rightarrow$ & Loyalitas Perilaku & 0,932 & 0,351 & Tidak Terbukti \\
\hline 6 & Kepercayaan & $\Rightarrow$ & Loyalitas Sikap & 4,145 & $* * *$ & Terbukti \\
\hline 7 & Kepercayaan & $\Rightarrow$ & Loyalitas Perilaku & 0,915 & 0,360 & Tidak Terbukti \\
\hline
\end{tabular}

Hasil pengujian hipotesis berdasarkan tabel 1.4. diatas adalah sebagai berikut:

1. Pengaruh CSR terhadap Kepuasan

Nilai CR untuk pengaruh variabel CSR terhadap kepuasan pada tabel diatas sebesar 4,879 dengan $\mathrm{p}$ value sebesar $0,000<0,05$. Dengan demikian hipotesis yang menyatakan bahwa terdapat pengaruh positif CSR terhadap kepuasan diterima.

2. Pengaruh CSR terhadap Kepercayaan

Nilai CR untuk pengaruh variabel CSR terhadap kepercayaan pada tabel diatas sebesar 4,737 dengan $\mathrm{p}$ value sebesar $0,000<0,05$. Dengan demikian hipotesis yang menyatakan bahwa terdapat pengaruh positif CSR terhadap kepercayaan diterima.

3. Pengaruh Kepuasan terhadap Kepercayaan

Nilai CR untuk pengaruh variabel kepuasan terhadap kepercayaan pada tabel diatas sebesar 2,540 dengan $\mathrm{p}$ value sebesar $0,011<0,05$. Dengan demikian hipotesis yang menyatakan bahwa terdapat pengaruh positif kepuasan terhadap kepercayaan diterima.

4. Pengaruh Kepuasan terhadap Sikap Loyalitas

Nilai CR untuk pengaruh variabel kepuasan terhadap sikap loyalitas pada tabel diatas sebesar 2,972 dengan $p$ value sebesar $0,003<0,05$. Dengan demikian hipotesis yang menyatakan bahwa terdapat pengaruh positif kepuasan terhadap sikap loyalitas diterima.

5. Pengaruh Kepuasan terhadap Perilaku Loyalitas

Nilai CR untuk pengaruh variabel kepuasan terhadap perilaku loyalitas pada tabel diatas sebesar 0,932 dengan $p$ value sebesar 0,351>0,05. Dengan demikian hipotesis yang menyatakan bahwa terdapat pengaruh positif kepuasan terhadap perilaku loyalitas ditolak.

6. Pengaruh Kepercayaan terhadap Sikap Loyalitas 
Nilai CR untuk pengaruh variabel kepercayaan terhadap sikap loyalitas pada tabel diatas sebesar 4,145 dengan $\mathrm{p}$ value sebesar 0,000 $<0,05$. Dengan demikian hipotesis yang menyatakan bahwa terdapat pengaruh positif kepercayaan terhadap sikap loyalitas diterima.

7. Pengaruh Kepercayaan terhadap Perilaku Loyalitas

Nilai CR untuk pengaruh variabel kepercayaan terhadap perilaku loyalitas pada tabel diatas sebesar 0,915 dengan $p$ value sebesar 0,360 >0,05. Dengan demikian hipotesis yang menyatakan bahwa terdapat pengaruh positif kepercayaan terhadap perilaku loyalitas ditolak.

8. Kepuasan dan kepercayaan terlihat memediasi pengaruh CSR terhadap loyalitas sikap. Namun tidak memediasi terhadap loyalitas perilaku.

\section{PEMBAHASAN}

Hasil penelitian menunjukan CSR berpengaruh terhadap Kepuasan. Semakin baik CSR yang memperlihatkan perusahaan menjalankan kewajibannya untuk melindungi dan meningkatkan kesejahteraan sosial masyarakat dan sekaligus perusahaan, baik dalam masa sekarang mau pun masa mendatang melalui berbagai upaya bisnis maupun tindakan sosial, dan memberikan keyakinan bahwa hal tersebut akan menghasilkan keuntungan yang seimbang dan terus menerus (sustainable) dalam jangka panjang bagi semua stakeholders, akan meningkatkan kepuasan pelanggan air mineral. Begitu pula sebaliknya, jika CSR yang diperlihatkan perusahaan buruk, akan dapat menciptakan kekecewaan pelanggan.

CSR berpengaruh terhadap Kepercayaan. Semakin baik CSR yang memperlihatkan perusahaan menjalankan kewajibannya untuk melindungi dan meningkatkan kesejahteraan sosial masyarakat dan sekaligus perusahaan, baik dalam masa sekarang mau pun masa mendatang melalui berbagai upaya bisnis maupun tindakan sosial, dan memberikan keyakinan bahwa hal tersebut akan menghasilkan keuntungan yang seimbang dan terus menerus (sustainable) dalam jangka panjang bagi semua stakeholders, akan dapat meningkatkan kepercayaan pelanggan air mineral. Begitu pula sebaliknya, jika CSR buruk,akan dapat menurunkan kepercayaan pelanggan.

Hasil penelitian menunjukan Kepuasan berpengaruh terhadap Kepercayaan. Semakin baik kepuasaanpelanggan yang ditunjukkan dengan senang dan bangganya pelanggan membeli dan mengonsumsi air mineral dalam kemasan, akan meningkatkan kepercayaan mereka terhadap merek air mineral yang mereka beli. Begitu pula sebaliknya, jika kepuasaan rendah,akan menyebabkanhilangnya kepercayaan pelanggan.

Hasil penelitian menunjukan Kepuasan berpengaruh terhadap LoyalitasSikap. Semakin besar kepuasanpelanggan akan meningkatkan loyalitasSikap mereka terhadap merek air mineral yang mereka beli. Begitu pula sebaliknya, jika pelanggan kecewa, loyalitassikap mereka akan menurun hingga hilang.

Kepuasan tidak berpengaruh terhadap LoyalitasPerilaku. Dengan demikian, dalam penelitian ini, tinggi atau rendahnya kepuasan tidak menjadi penentu bagi tindakan 
pelanggan untuk tetap membeli atau mengonsumsi suatu merek air mineral dalam kemasan tertentu. Kondisi ini terjadi bisa saja karena air mineral dalam kemasan adalah produk sejenis yang tidak memiliki perbedaan. Sehingga kepuasan pelanggan cenderung sama antara satu merek dengan merek lainnya sehingga cenderung pelanggan tidak menjadikannya basis keputusan kesetiaan mereka.

Hasil penelitian menunjukan Kepercayaan berpengaruh terhadap LoyalitasSikap. Semakin kuat kepercayaan pelangganmaka semakin meningkatkan kesetiaan sikap mereka yang ditunjukan dengan dukungan dan sikap positif terhadap merek tertentu. Begitu pula sebaliknya, jika kepercayaan pelanggan semakin hilang karena perusahaan terlihat tidak peduli dan bertanggung jawab maka akan mengurangi hingga hilang loyalitas sikap pelanggan.

Kepercayaan tidak berpengaruh terhadap LoyalitasPerilaku. Dengan demikian, temuan penelitian ini menunjukkan bahwa tingkat kepercayaan pelanggan terhadap merek air mineral tertentu tidak lah menentukan atau menjadi sebab mereka tetap setia membeli merek tertentu atau beralih merek. Kondisi ini terjadi bisa saja karena air mineral dalam kemasan bukanlah produk yang memiliki resiko tinggi, sehingga cenderung pelanggan tidak menjadikannya basis keputusan kesetiaan mereka.

Kepuasan dan kepercayaan menjadi variabel yang memediasi pengaruh CSR terhadap loyalitas sikap. Namun tidak memediasi terhadap loyalitas perilaku. Dengan demikian, CSR dapat meningkatkan loyalitas sikap pelanggan melalui perbaikan atau peningkatan kepuasan dan kepercayaan pelanggan mereka.

\section{KESIMPULAN}

Temuan penelitian ini membuktikan CSR berpengaruh terhadap Kepuasan. Semakin baik CSR yang dijalankan perusahaan, akan meningkatkan kepuasan pelanggan air mineral. Dengan demikian, penting bagi perusahaan untuk menjalankan program CSR yang mampu menciptakan kepuasan dan mencegah kekecewaan pelanggan. CSR terbukti berpengaruh terhadap Kepercayaan. Semakin baik CSR dijalankan perusahaan, akan dapat meningkatkan kepercayaan pelanggan air mineral. Perusahaan perlu menjalankan program CSR yang mampu membangun kepercayaan pelanggan akan kepedulian dan tanggung jawab perusahaan terhadap pelanggan.

Kepuasan terbuktiberpengaruh terhadap Kepercayaan. Semakin baik kepuasaan pelanggan akan meningkatkan kepercayaan mereka terhadap merek air mineral yang mereka beli. Perusahaan perlu memperhatikan dan meningkatkan kepuasan pelanggan karena ini berdampak pada kepercayaan pelanggan.Kepuasan dan kepercayaan pelanggan terbuktiberpengaruh terhadap LoyalitasSikap. Semakin besar kepuasan dan kepercayaan pelanggan akan meningkatkan loyalitasSikap mereka terhadap merek air mineral yang mereka beli. Perusahaan perlu memperhatikan dan meningkatkan kepuasan dan kepercayaan pelanggan karena ini dapat menciptakan sikap loyal terhadap merek.Kepuasan dan kepercayaan tidak berpengaruh terhadap LoyalitasPerilaku. Walaudemikian 
membangun kepuasan dan kepercayaan pelanggan tetap memilki manfaat menciptakan sikap loyal mereka. Kepuasan dan kepercayaan tampaknya menjadi variabel yang memediasi pengaruh CSR terhadap loyalitas sikap. Dengan demikian, CSR dapat meningkatkan loyalitas sikap pelanggan melalui perbaikan atau peningkatan kepuasan dan kepercayaan pelanggan mereka.

\section{DAFTAR PUSTAKA}

Ahmad Jamal. et. al. 2009. Investigating the Effects of Service Quality Dimensions and Expertise On Loyalty. European Journal of Marketing. Vol.43,No.3, 398-420.

Ahmed, I., Shankat, M. Z., Nawaz, M. M., Ahmed, N., \& Usman, A. (2011). Determinants of The Satisfaction and Repurchase Intentions of Users of Short Messenger Services (SMAS): A Study in The Telecom Sector of Pakistan. International Journal of Management, 28, 763-772.

Alex Wang. 2011. The Effects of Firms'Advertising Disclosures as a Reflection of CSR Parctices On Consumer Responses. Social Responsibility Journal. Vol.7,No.4, 592603.

Barnes. AJ. 2011. Corporate Social Responsibility and Its Effects On Brand Trust. Auckland University of Technology Business Scholl.

Barsky, D.J. And Labagh, R. (1992), “A Strategy for Customer Satisfaction: The Cornell Hotel and Restaurant Administration Quarterly", Volume 33, Issue 5, October 1992, Pages 32-40

Bowen, J.T. and Chen, S.L. (2001), „,,The relationship between customer loyalty and customer satisfaction eee, International Journal of Contemporary Hospitality Management, Vol. 13 No. 5, pp. 213-7.

C. B. Bhattacharya , Sen S (2003). Consumer-Company Identification: A Framework for Understanding Consumers' Relationships with Companies. Journal Of Marketing, J. Mark., 67: 76-88.

Chahal.et.al. 2006. Implications of Corporate Social Responsibility on Marketing Performance : A Conceptual Framework. Journal of Services Research. 205-216.

Chapple.et.al. 2005. Corporate Social Responsibility (CSR) In Asia. Business and Society. Vol. 44 No.4.

Chaudhuri.and Holdbrook. 2001. The Chain of Effects From Brand Trust and Brand Affect to Brand Performance: The Role of Brand Loyality. Journal of Marketing. Vol.65, $81-93$

Day.G.S. 1969. A Two Dimensional Concept on Brand Loyality. Journal of Advertising research. Vol.9, No.3, 29-35. 
Dick.A.et.al. 1994. Customer Loyalty:Toward an Integrated Conceptual Framework. Journal of Academy of Marketing Science.Vol.22, No.2, 99.113.

Gefan.D. 2002. Customer Loyalty In E-Commerce. Journal of the Association of Information Systems. Vol.3,27-51.

Griffin, Jill. 2003. Customer Loyalty : Menumbuhkan Dan Mempertahankan. Pelanggan.Penerbit Erlangga. Jakarta.

Hair et al. 2006.Multivariate Data Analysis, $6^{\text {th }}$ ed.Upper Saddle River, New Jersey: Pearson Education.

Jasfar, Farida. 2012. Teori dan Aplikasi Sembilan Kunci Keberhasilan Bisnis Jasa: Sumber Daya Manusia, Inovasi, Dan Kepuasan Pelanggan. Jakarta: Salemba Empat.

Koontz.et.al. 2003. Essential of Management. Fourth Edition. New York:Mcgraw-Hill.

Kotler.P.et.al. 2005. Corporate Responsibility: Doing the Most Good for Your Company and Your Cause. Wiley. New Jersey: Hoboken.

Kotler.P.et.al. 2008. Principles of Marketing. 12 ${ }^{\text {th }}$ ed. Upper Saddle River.NJ: Pearson Education.

Kwok T.Y. 2007. The Effect of Customer Trust on Customer Loyalty and repurcahse Intention: The Moderating Influence of Preceived CSR. Hongkong Baptist University. 75.

Nooteboom. 2003. The New Imperialism. Oxford: Oxford University Press. Hiariej, Eric.

Roberts, L. W., Warner, T. D., Brody, J. L., Nguyen, K. and Roberts, B. B. (2003). What is ethically important in clinical research? A preliminary study of attitudes of 73 psychiatric faculty and residents. Schizophrenia Bulletin 29(3), 607-613

Rujirutana Mandhachitara, Yaowalak Poolthong, (2011) "A model of customer loyalty and corporate social responsibility", Journal of Services Marketing, Vol. 25 Issue: 2, pp.122-133,

Kennedy, D.., 2001. Functional Endoscopic Sinus Surgery: Concepts, Surgical Indications, and Instrumentation. In D. Kennedy, W. Bolger, \& S. Zinrech, eds. Diseases of the Sinuses Diagnosis and Management. Ontario: BC Decker Inc, pp. 197-210.

Koontz, H and Weihrich, H (2003). "Management." 9th Edition, Mc- Graw Hill Book Company, New York. Pp.391-460

Luo, Xueming \& Bhattacharya C.B, "Corporate Social Responsibility, Custtomer Satisfaction and Market Value", Journal of Marketinmg Vol.70 (October 2006)

Plank, E.R., Reid, D.A dan Pullins, E.B., 1999, Perceived Trust in Business -to -Business Sales: A New Measure, Journal of Personal Selling \& Sales Management, Volume XIX, Number 3, Summer: $61-71$. 
Sheng, T., \& Liu, C. (2010). An Empirical Study on The Effect Of E-Service Quality on Online Customer Satisfaction and Loyalty. Nankai Business Review International, 1(3), 273-283. https://doi.org/10.1108/20408741011069205

Wang, H. C. (2011). Corporate social responsibility and corporate financial performance in China: an empirical research from Chinese firms. The international journal of business in society, 11(4) $361-370$. 